\title{
Effect of solvents on the morphology of PMMA films fabricated by spin-coating
}

\author{
Giovana da Silva Padilha ${ }^{1 *}$, Virginia Mansanares Giacon² and Julio Roberto Bartoli \\ ${ }^{1}$ Centro de Pesquisa em Manufatura de Materiais Avançados, Faculdade de Ciências Aplicadas - FCA, \\ Universidade Estadual de Campinas - UNICAMP, Limeira, SP, Brazil \\ ${ }^{2}$ Departamento de Engenharia de Materiais, Universidade Federal do Amazonas - UFAM, Manaus, AM, \\ Brazil \\ ${ }^{3}$ Departamento de Engenharia de Materiais e de Bioprocessos, Faculdade de Engenharia Química - FEQ, \\ Universidade Estadual de Campinas - UNICAMP, Campinas, SP, Brazil
}

*giovana.padilha@fca.unicamp.br

\begin{abstract}
A method to produce thin layer of PMMA (poly (methyl methacrylate) films by spin coating is reported. PMMA is dissolved in xylene, a mixture of MIBK-xylene and chloroform. Varying the PMMA concentration and spin-coating speeds controls the thickness of the PMMA films. Using chloroform as solvent evidenced thickness around $10 \mu \mathrm{m}$. This thickness is suitable for core of optical polymeric films. These PMMA films with lower roughness are treated with $\mathrm{CHF}_{3}$ plasma to produce the cladding. The morphology of PMMA films is analyzed by atomic force microscopy and scanning electron microscopy. Profilometry, metricon and contact angle analysis are associated with the effective parameters in roughness and their effect before and after plasma treatment. Gel permeation chromatography (GPC) is used for estimating molecular weights of PMMA.
\end{abstract}

Keywords: PMMA, spin-coating, solvent effect, morphology, $\mathrm{CHF}_{3}$ plasma.

\section{Introduction}

Poly (methyl methacrylate) (PMMA) is the most important thermoplastic polymer that has been widely used in various industrial fields due to its transparency, light weight and low $\cos ^{t^{[1]}}$. It can substitute glass in several hard-use products such as antiriot vehicles, and it can be used in different technological applications, such as optical devices, optical lenses, and in gratings or waveguides ${ }^{[2-4]}$. In the field of optics, PMMA has been studied due to the intrinsic versatility of its molecular structure, which allows for enhanced refractive index modeling for core material, and also for the ease of manufacturing process and patterning capability ${ }^{[5,6]}$. In the preparation of PMMA films, spin-coating can be used mainly because it allows fast and reproducible large scale production. Basically, the polymer solution is deposited on a static substrate, which is rotated at a given angular velocity during a given period of time (Figure 1).

The thickness of the resulting films depends on the concentration of the polymer in solution, polymer molecular weight, spinning velocity, and spinning time ${ }^{[8-11]}$. Solvents have been used to dissolve PMMA to obtain solutions. Hamdy et al. ${ }^{[4]}$ dissolved PMMA in chloroform to produce transparent blue thin films/sheets using methylene blue dye (MB) as a dopant in PMMA for UV sensors. In Liu et al. ${ }^{[12]}$ PMMA was dissolved in a binary solvent of $\mathrm{N}, \mathrm{N}$-dimethylacetamide and acetone to investigate the effect of solvents on solution properties and electrospun PMMA membrane morphology. Using different solvents, different PMMA morphologies and thicknesses can be obtained, and

the type of solvent selected plays an important role in the uniformity and thickness of the PMMA films. A solvent with lower vaporizability results in better uniformity and lower thickness. Thus, the solvent should be selected based on the desired thickness and uniformity ${ }^{[13,14]}$.

Previous works showed PMMA films of $14 \mu \mathrm{m}$ as core of planar polymeric waveguides ${ }^{[3]}$. Thickeness around $10 \mu \mathrm{m}$ improving the connect in optical fiber, waveguides and optical interconect ${ }^{[3]}$. Then, the present work we attempt to compare the influence of spin-coating speeds and the concentration of PMMA dissolved in different solvents. A treatment of plasma on PMMA surface films around $10 \mu \mathrm{m}$ of thickness was carried out. The morphology and roughness of PMMA films, before or/and after plasma treatment, were analyzed by atomic force microscopy (AFM), scanning electron microscopy (SEM), water contact angle measurement, refractive index and proflilometry.

\section{Materials and Methods}

\subsection{Materials}

PMMA was purchased from Rohm \& Hass (Philadelphia, USA). Xylene, MIBK (methyl isobutyl ketone) and chloroform were supplied by Synth (Diadema, Brazil). All reagents were analytical grade and were used as received without further treatment. (100) Silicon substrates (10-20 ohm.cm, one-side polished, 0.610-0.640 $\mathrm{mm}$ thickness, and $75 \mathrm{~mm}$ diameter) were supplied from University Wafer (Boston, USA). 


\subsection{Methods}

\subsubsection{Gel Permeation Chromatography}

Number average molecular weight $(\mathrm{Mn})$, weight average molecular weight $(\mathrm{Mw})$, peak molecular weight $(\mathrm{Mp})$ and poly-dispersity $(\mathrm{Mw} / \mathrm{Mn})$ of PMMA and the polymer standards were determined by gel permeation chromatography (GPC) (Waters 410) equipped with three columns arranged in sequence (HR-3, HR-4 and HR-5) with the stationary phase of styrene-divinylbenzene with pore dimensions of $10^{3}, 10^{4}$ and $10^{5} \AA$, respectively. A constant flow of $1 \mathrm{~mL} / \mathrm{min}$ of tetrahydrofuran (THF) solution was used. PMMA samples were solubilized at $0.1 \%(\mathrm{w} / \mathrm{w})$ in THF and injected into the chromatograph $(100 \mu \mathrm{L})$. The column oven and refractive index temperature were maintained at $40{ }^{\circ} \mathrm{C}$. The molecular weight was determined using the software program Millennium 2010.

\subsubsection{Preparation of PMMA solutions for spin-coating and plasma PMMA films}

PMMA coatings were prepared by spin-coating using a PWM32 spin-coater by Headway Research Inc. The spin-coating solution consisted of PMMA (Plexiglas - VO 052) dissolved at a concentration in distinct solvents - xylene, a mixture of MIBK-xylene, and chloroform. The ratio of MIBK-xylene was $1: 1(\mathrm{v} / \mathrm{v})$. The concentration of polymer and spin-coating speed were selected to provide a homogenous coating thickness over the entire silicon. The range and level of the independent variables and coded values are presented in Table 1. The presence of solvents in the PMMA films was monitored until mass was kept constant.

PMMA films with thicknesses of $10 \mu \mathrm{m}$ were exposed to $\mathrm{CHF}_{3}$ gas plasma in a parallel plate reactor (ACG 3PT, Serial 587 - ENIRF Inc.) connected to a radio frequency (RF) power source $(13.56 \mathrm{MHz})$. The plasma chamber is made of stainless steel and the electrode uses water as a coolant. The chamber can accommodate up to 12 samples altogether in one round of deposition. The gas inlet is located at the top of the chamber, while the bottom has circular grooves to fit samples and position them at the

Table 1. Factors and their levels used for two-level factorial design experiment.

\begin{tabular}{lccc}
\hline \multicolumn{1}{c}{ Test set } & $\begin{array}{c}\text { Level } \\
\text { botton }(-\mathbf{1})\end{array}$ & $\begin{array}{c}\text { Central } \\
\text { point (0) }\end{array}$ & $\begin{array}{c}\text { Level up } \\
(+\mathbf{1})\end{array}$ \\
\hline Concentracion $(\mathrm{g} / \mathrm{L})$ & 10 & 15 & 20 \\
Speed $(\mathrm{rpm})$ & 1,000 & 1,500 & 2,000 \\
\hline
\end{tabular}

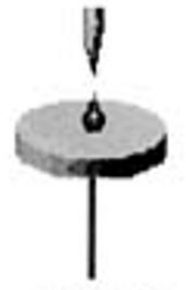

Stage 1

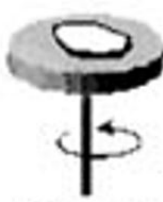

Stage 2

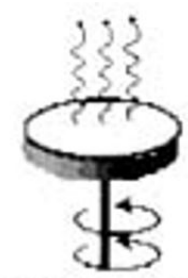

Stages 3 \& 4
Figure 1. Spin-Coating procedure ${ }^{[7]}$. same level (Figures $2 \mathrm{a}$ and $2 \mathrm{~b}$ ). After polymerization, the samples were wrapped in paraffin and stored in a petri dish for further analysis.

\subsection{Characterization of PMMA films}

\subsubsection{Thickness measurements and refractive index}

Gravimetry $\left(10^{-5} \mathrm{~g}\right)$ technique was used to estimate thickness of the PMMA films, using density of pure PMMA. The thickness of PMMA films and refractive index of the fluorinated film and PMMA film was confirmed by metricon prism coupler (METRICON 2010, $\lambda=632.8 \mathrm{~nm}$ ).

\subsubsection{Atomic force microscopic measurements of surfaces}

The surface topography and roughness of the PMMA films were studied using an atomic force microscopy (AFM) (Auto Probe CPII Park Scientific Instrument). Scans of $100 \mu \mathrm{m}$ are recorded in noncontact mode with a silicon probe with a curvature radius of less than $10 \mathrm{~nm}$, a constant force of $1.75 \mathrm{~N} / \mathrm{m}$ and operating at a resonance frequency of $155 \mathrm{kHz}$. The root mean square roughness was calculated over the surface $(5 \times 5 \mu \mathrm{m})$.

\subsubsection{Surface morphology using scanning electron microscopy}

The morphologies of silicon and PMMA films surfaces were observed using a scanning electron microscopy (SEM) (440i LEO). Samples were cut $(0.7 \times 0.4 \mathrm{~cm})$ and covered with gold, operating at an acceleration voltage of $5 \mathrm{kV}$.

\subsubsection{Profilometry measurements of roughness}

Roughness parameters of silicon and PMMA films before and after plasma treatment were obtained by profilometry (Dektac-Veeco-6M). A diamond probe traversed all samples $(5,000 \mu \mathrm{m}$ - central region for $30 \mathrm{~s}$, with a vertical resolution of $650 \mathrm{k} \AA$ ) in different areas.

\subsubsection{Contact angle measurements}

The water contact angles of all the surfaces were measured using contact angle of surface wetting (Tantec Half-Angle CAM - MICRO), with deionized water. The contact angle was measured at three different points on each sample and the average values of triplicate samples were reported.

\section{Results and Discussions}

The average molecular weight of PMMA studied by GPC is shown in Table 2. The value measured for PMMA is in agreement with the reported in literature for spin-coated films ${ }^{[15]}$.

PMMA was dissolved in xylene, a mixture of MIBK-xylene and chloroform. Chloroform was the fastest solvent to dissolve $\operatorname{PMMA}\left(2 \mathrm{~h}\right.$ at $\left.25^{\circ} \mathrm{C} \pm 1^{\circ} \mathrm{C}\right)$, followed by the MIBK-xylene mixture $\left(8 \mathrm{~h}\right.$ at $\left.50^{\circ} \mathrm{C} \pm 2{ }^{\circ} \mathrm{C}\right)$. Xylene was the solvent with

Table 2. Mn (number molecular weight), Mp (peak molecular weight), Mw (weight average molecular weight) and Mw/Mn (poly-dispersity) of the PMMA.

\begin{tabular}{ccccc}
\hline & $\bar{M}_{\boldsymbol{n}}(\mathrm{g} / \mathbf{m o l})$ & $\overline{\mathbf{M}}_{\mathbf{p}(\mathrm{g} / \mathbf{m o l})}$ & $\overline{\boldsymbol{M}}_{\boldsymbol{w}(\mathrm{g} / \mathbf{m o l})}$ & $\overline{\boldsymbol{M}}_{\boldsymbol{w} / \bar{M}_{\boldsymbol{n}}}$ \\
\hline PMMA & 73.143 & 120.045 & 115.116 & 1.57 \\
\hline
\end{tabular}


greatest dissolution time $\left(9 \mathrm{~h}\right.$ at $\left.50{ }^{\circ} \mathrm{C} \pm 2{ }^{\circ} \mathrm{C}\right)$. Although MIBK solvent can also be used to solubilize PMMA, it was not used in this work because of its solubility parameter. The miscibility of a polymer can be determined quantitatively by the difference between $\delta_{\mathrm{p}}$ (polymer solubility) and $\delta_{\mathrm{s}}$ (solvent solubility), where solvents may be classified as good, medium and bad for a given polymer ${ }^{[16]}$. Based on this, chloroform, which has a solubility parameter range around $19.03\left(\mathrm{~J}^{1 / 2} \mathrm{~cm}^{-3 / 2}\right)$ is a good solvent for PMMA that has solubility parameter of $19.0\left(\mathrm{~J}^{1 / 2} \mathrm{~cm}^{-3 / 2}\right)$. MIBK has no a good solubility parameter for PMMA - $17.2\left(\mathrm{~J}^{1 / 2} \mathrm{~cm}^{-3 / 2}\right)$, which provides a difference greater than 1.5. In the case of using the mixture of MIBK-xylene, the solubility is the average of those of the pure solvents ${ }^{[17]}$. However, it is not just the type of solvent/polymer that influences the process. Other variables inherent to the structure of the polymer significantly contribute to the solubility process. High crystallinity and high molecular weights have a negative effect, which makes it more difficult to choose an appropriate solvent ${ }^{[18]}$.

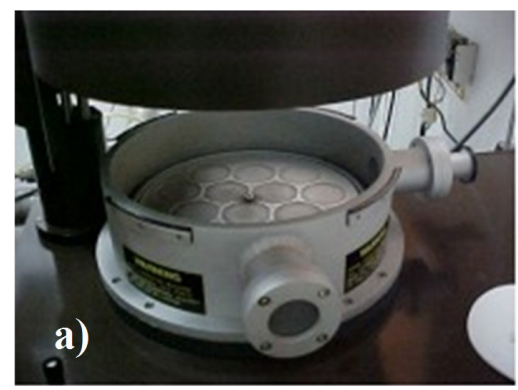

The response surface methodology for seven factorial design experiments for each solvent is presented in Table 3. Data analysis was done using the Statistica program (version 6.0). It was found that both the dissolved PMMA into xylene and the MIBK-xylene mixture have induced thinner thicknesses than the chloroform solvent, as expected, considering similar conditions. Variance analysis of the films thicknesses obtained using factorial design is presented in Table 4. It shows that the $\mathrm{F}_{\text {calculated }}$ value for the regression using chloroform was 68.4 , while the $\mathrm{F}_{\text {critical }}$ value $(\mathrm{p}=0.05$, degrees of freedom for regression: 3 ; degrees of freedom for residual: 3 ) was 9.28 , validating the response surface shown in Figure 3 with a determination coefficient $\left(\mathrm{R}^{2}\right)$ of 0.98 . The mathematical model generated is shown in Equation 1 ( $\mathrm{X}_{1}$ : chloroform concentration and $\mathrm{X}_{2}$ : spin-coating speed). Other solvents, by $\mathrm{F}_{\text {calculated }}$ less than the $\mathrm{F}_{\text {critical }}$ value were not shown in the response surface.

$$
\text { thickeness }=12.1+7.28 * X_{1}-2.05 * X_{2}-1.29 * X_{1} * X_{2}
$$

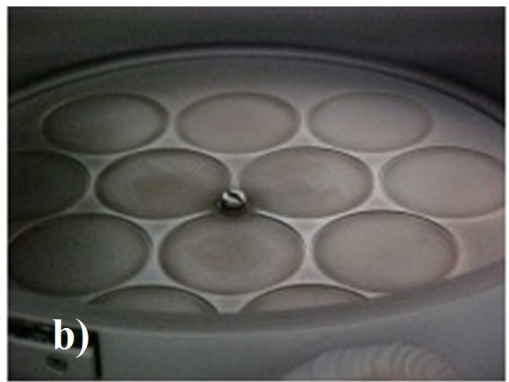

Figure 2. (a) plasma apparatus; (b) internal reactor (bottom electrode).

Table 3. Thickness of PMMA films dissolved in xylene, MIBK-xylene mixture and chloroform

\begin{tabular}{|c|c|c|c|c|}
\hline \multirow{2}{*}{$\begin{array}{l}\text { PMMA concentration } \\
(\mathrm{g} / \mathrm{L})\end{array}$} & \multirow{2}{*}{$\begin{array}{l}\text { Spin-Coating speed } \\
(\text { rpm) }\end{array}$} & \multicolumn{3}{|c|}{ Thin films $(\mu \mathrm{m})$} \\
\hline & & Xylene & MIBK-xylene & Chloroform \\
\hline 10 & 1,000 & $1.99 \pm 0.3$ & $1.69 \pm 0.2$ & $6.02 \pm 0.1$ \\
\hline 20 & 1,000 & $7.70 \pm 0.5$ & $7.57 \pm 0.1$ & $23.17 \pm 0.3$ \\
\hline 10 & 2,000 & $1.48 \pm 0.2$ & $1.45 \pm 0.2$ & $4.48 \pm 0.2$ \\
\hline 20 & 2,000 & $4.86 \pm 0.3$ & $5.21 \pm 0.3$ & $16.48 \pm 0.3$ \\
\hline 15 & 1,500 & $1.77 \pm 0.8$ & $4.42 \pm 0.2$ & $10.58 \pm 0.6$ \\
\hline 15 & 1,500 & $2.56 \pm 0.3$ & $4.16 \pm 0.5$ & $11.56 \pm 0.5$ \\
\hline 15 & 1,500 & $2.04 \pm 0.5$ & $5.55 \pm 0.1$ & $12.41 \pm 0.3$ \\
\hline
\end{tabular}

Table 4. Variance analysis of the PMMA films thickness.

\begin{tabular}{|c|c|c|c|c|c|}
\hline \multicolumn{6}{|c|}{ Xylene } \\
\hline Effect & SS & DF & MS & $\mathbf{F}_{\text {calculated }}$ & $\mathbf{F}_{\text {critical }}$ \\
\hline Regression & 24.82 & 3 & 8.27 & 3.86 & 9.28 \\
\hline Error & 0.32 & 2 & 0.16 & & \\
\hline Total & 31.23 & & & & \\
\hline \multicolumn{6}{|c|}{ MIBK-xylene } \\
\hline Effect & SS & DF & MS & $\mathbf{F}_{\text {calculated }}$ & $\mathbf{F}_{\text {critical }}$ \\
\hline Regression & 31.85 & 3 & 10.62 & 10.41 & 9.28 \\
\hline Error & 2.34 & 2 & 1.17 & & \\
\hline Total & 34.91 & & & & \\
\hline \multicolumn{6}{|c|}{ Chloroform } \\
\hline Effect & SS & DF & MS & $\mathbf{F}_{\text {calculated }}$ & $\mathbf{F}_{\text {critical }}$ \\
\hline Regression & 235.99 & 3 & 78.66 & 68.4 & 9.28 \\
\hline Error & 1.68 & 2 & 0.84 & & \\
\hline Total & 239.46 & & & & \\
\hline
\end{tabular}


However, using a nonlinear first-order model for the film thickness variable (Equation 1), the exact value was determined: 1,900 rpm (spin-coating speed) and $15.36(\mathrm{~g} / \mathrm{L})$ (concentration of PMMA) for films around of $10 \mu \mathrm{m}$.

To understand the behavior of PMMA films dissolved in xylene, the mixture of MIBK-xylene and chloroform, atomic force microscopy study has been carried with PMMA films obtained in $20 \mathrm{~g} / \mathrm{L}$ and 1,000 rpm (xylene and MIBK-xylene) and $15.36 \mathrm{~g} / \mathrm{L}$ and 1,500 rpm for chloroform. PMMA films dissolved in xylene with thickness of $7.70 \mu \mathrm{m}$ (Figure 4a) and MIBK-xylene with thickness of $7.57 \mu \mathrm{m}$ (Figure $4 \mathrm{~b}$ ) showed increasing peaks and values ( $276 \mathrm{~nm}$ and $237 \mathrm{~nm}$, respectively) compared to PMMA films dissolved in chloroform (171 nm) (Figure $4 \mathrm{c}$ ). The attained thin films of both the xylene and MIBK-xylene mixture showed morphological changes with larger formations of convection cells than the film dissolved in chloroform. This behavior seems to be associated with the physico-chemical properties of the solvents. In case of solvent evaporation, convection cells structures can be formed ${ }^{[19]}$. Yamamura et al. ${ }^{[19]}$ showed that solvent-drying rates provided quantitative information for the concentration variation in the phase-separating solutions, which lead to the formation of the particular cellular patterns. With decreasing air velocity in polymeric films, the transition from the cellular

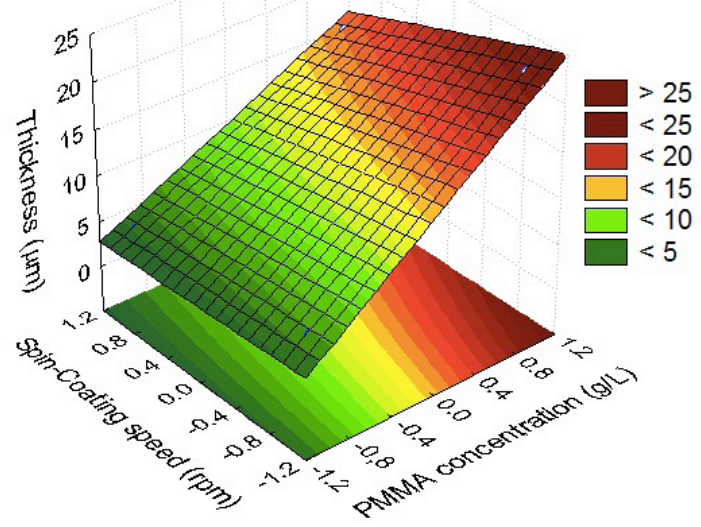

Figure 3. Response surface of the effect of thickness of PMMA films $(\mu \mathrm{m})$ as function of spin-coating speed (rpm) and chloroform concentration $(\mathrm{g} / \mathrm{L})$. patterns to the pattern-free structures occurred. However, these features can be used to control the process conditions, such as rotation and spinner deposition time, as well as the solids concentration in solution.

Surface roughness measurement using AFM showed that average root mean square (rms) of PMMA films in xylene, MIBK-xylene and chloroform was 20, 20 and $15 \mathrm{~nm}$, respectively. However even using the non-contact mode, PMMA films showed stripes probably by film fragility. These stripes were observed in all samples. PMMA films dissolved in chloroform showed reduction of roughness using AFM. The morphological in the silicon substrate and PMMA films dissolved in chloroform over silicon were observed using scanning electron microscopy and the SEM micrographs are showed in Figure 5. Silicon exhibited a plane surface (Figure 5a), but when PMMA was dissolved in chloroform we observed roughness by formation of clusters and clumps, with structures non-uniform in the PMMA films deposited on silicon. Figure 5b shows the micrograph of PMMA films over silicon exhibiting rough surface structure. To discuss the appearance of PMMA film dissolved in chloroform, the film was removed from the silicon and the micrograph is show in Figure 5c. The appearance of the film without the silicon shows great morphological difference indicating clearly the intrinsic characteristic of convection cells structures confirmed by the AFM analysis.

Padilha et al. ${ }^{[20]}$ studied the effect of plasma treatment on the deposition of films fluorinated over PMMA, the results showed that films treated using $\mathrm{CHF}_{3}$ plasma obtained acceptable thickness for optical devices. Under these conditions, a profilemeter analysis has been carried out. Their results are shown in Table 5. These results showed that the time was a factor in films that were smoother after plasma treatment using 0.7 torr - $1423 \AA$ (40 $\mathrm{min})$ to $4402 \AA$ (20 min) on $10 \mu \mathrm{m}$ PMMA films. This behavior has also been observed in samples at 0.3 torr and $30 \mathrm{~min}$ as shown in Table 5. Figure 6 shows a comparison of the silicon substrate, whose value was not detected by the device due to measured roughness above $25 \AA$ (silicon shows a low roughness, close to $3 \AA^{[21]}$ ), and the both roughness of PMMA film dissolved in chloroform and plasma deposited on PMMA (0.7 torr and $20 \mathrm{~min}$.).

In fact, it is possible to fabricate optical polymeric films. Therefore, just varying plasma time over PMMA films, low roughness can be obtained. Giacon et al. ${ }^{[3]}$ showed that thickness for the fluorinated film around $0.57 \mu \mathrm{m}$ was
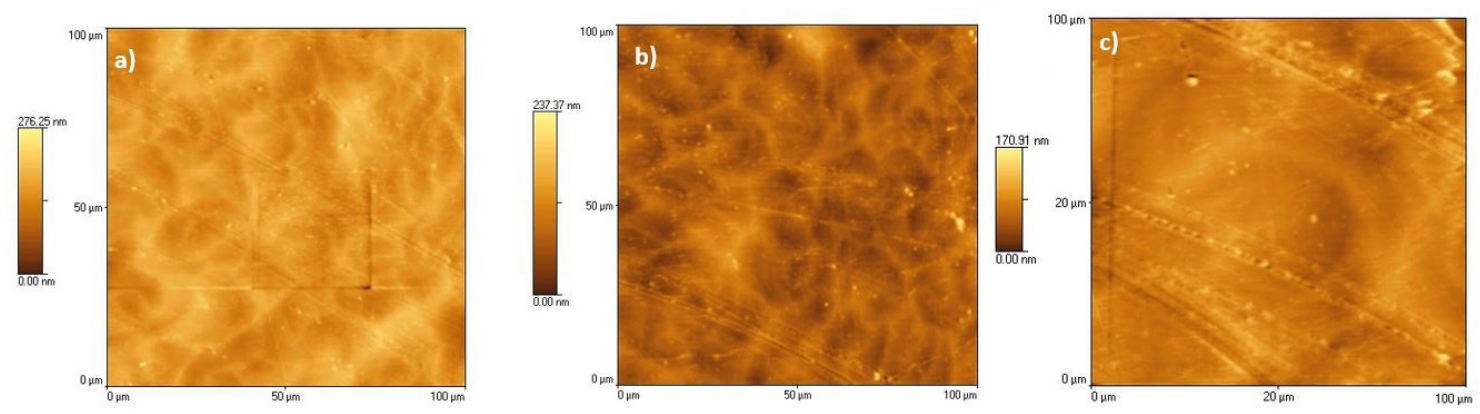

Figure 4. Atomic force microscopy (a) PMMA dissolved in xylene; (b) PMMA dissolved in MIBK-xylene; (c) PMMA dissolved in chloroform. 

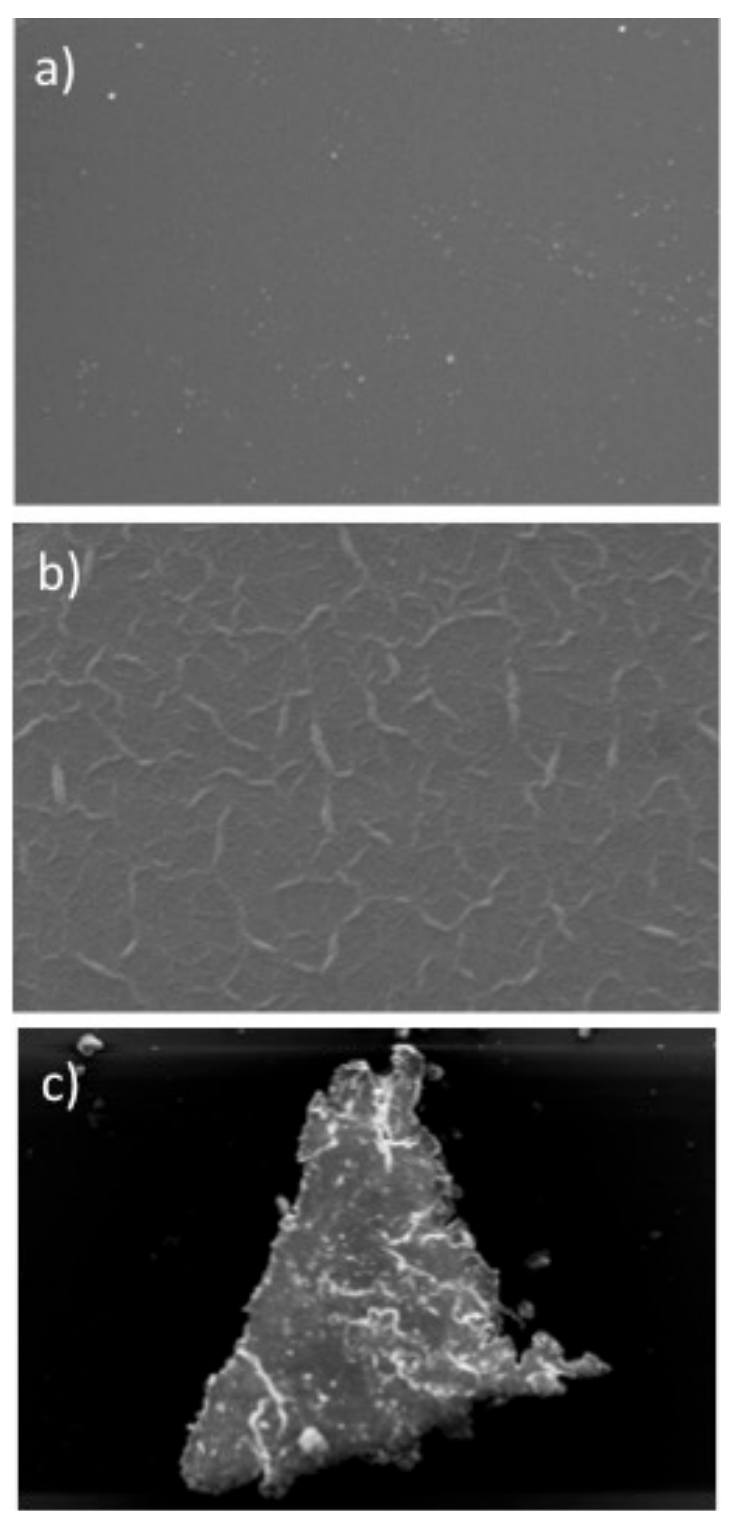

Figure 5. Scanning electron microscopy (a) silicon; (b) PMMA dissolved in chloroform; (c) PMMA film without the silicon.

Table 5. Plasma films roughness by profilometry.

\begin{tabular}{ccc}
\hline \multicolumn{2}{c}{ Plasma Process } & $\begin{array}{c}\text { Roughness ( } \text { A) After } \\
\text { plasma }\end{array}$ \\
\cline { 1 - 2 } Pressure (torr) & Time (min) & $2059 \pm 125$ \\
0.3 & 20 & $1423 \pm 101$ \\
0.7 & 20 & $3400 \pm 98$ \\
0.5 & 30 & $3701 \pm 113$ \\
0.3 & 40 & $4402 \pm 99$ \\
0.7 & 40 & \\
\hline
\end{tabular}

suitable for cladding of PMMA with core of $14 \mu \mathrm{m}$. While Padilha et al. ${ }^{[20]}$ observed $0.61 \mu \mathrm{m}$ of fluorinated polymer at 0.7 torr and $20 \mathrm{~min}$. In this present work, PMMA films treated with plasma showed low roughness at this plasma condition. This observation can be explained by decrease of the contact time of $\mathrm{CHF}_{3}$ with the samples.

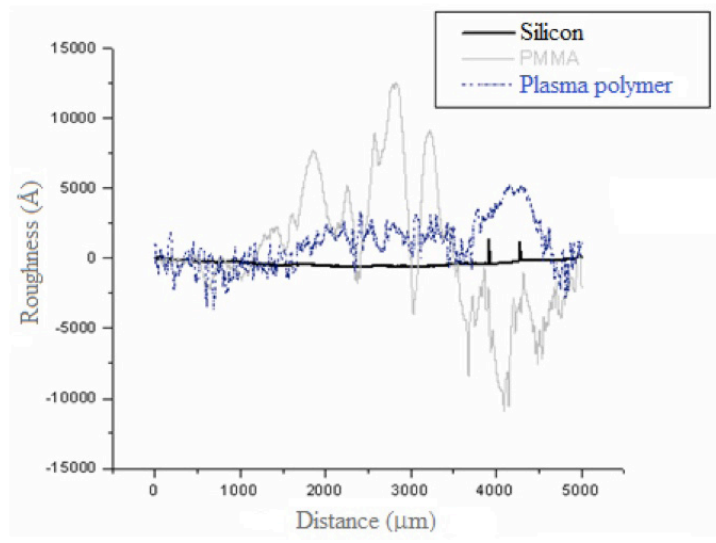

Figure 6. Roughness analysis of silicon, PMMA film dissolved in chloroform and plasma over PMMA film.

Contact angle measurement for the PMMA dissolved in chloroform (before plasma treatment) was $71.3^{\circ} \pm 3.4$, where the typical value is $70.5^{\circ} \pm 3.1^{[22]}$. PMMA samples exposed to $\mathrm{CHF}_{3}$ plasma shows a significant increase in the contact angle (the average of all samples after plasma treatment was $105.5^{\circ} \pm 3.4$ ) in relation to the original PMMA and very close to the reported for fluorinated polymer PTFE $\left(110^{\circ}\right)^{[23]}$, proving that plasma treatment can get a good modification for films. This modification of PMMA film surface can be explained by the presence of fluorine atoms that decrease the surface free energy, increasing the values of contact angle ${ }^{[24,25]}$.

PMMA studies showed low level of attenuation in optical devices. Usually, the cladding has slightly smaller refractive index than pure PMMA. Bartoli et al. ${ }^{[26]}$ observed greater speed and higher quality of transmission in polymeric optical fibers. PMMA was coated with hydrofluorocarbon (HFC) plasma. The reduced gradually of the refractive index in coating layer allowed performance gains.

The refractive index of PMMA solved in chloroform was 1.49. However, after of the plasma treatment the refractive index of 1.41 was attained. In similar cases, when plasma of $\mathrm{CF}_{4}+\mathrm{H}_{2}$ was deposited on PMMA, the refractive index was $1.43^{[26]}$. Thus, plasma treatment used in this study to produce polymeric optical films allows polymer waveguides to be manufactured, with a numerical aperture (NA) near 0.5 . Polymeric structures generally have been manufactured with an NA between 0.3 and 0.5 , and the structure of silica with NA of about 0.14 is attained, as previously reported ${ }^{[27]}$. The use of chloroform as a solvent can contribute to an acceptable roughness for polymeric optical films.

\section{Conclusions}

PMMA films dissolved in chloroform showed acceptable roughness for thin films when compared with other solvents - xylene and the mixture of MIBK-xylene. PMMA dissolved in chloroform - $15.36(\mathrm{~g} / \mathrm{L})$, produced films with thickness of $10 \mu \mathrm{m}$ by spin coating. These films were exposed to $\mathrm{CHF}_{3}$ plasma. Using chloroform to dissolve PMMA, tiny and shallow cells were created according to AFM results, 
while deep cells with frequent cavities were observed for different solvents. Both SEM and AFM analyses have revealed typical cell structures. Plasma treatment has favored to decrease the roughness, as detected using profilemeter. Profilemeter results showed different values of roughness according to plasma process (1423 \pm 101 to $4402 \pm 99)$. The contact angle confirmed modification on the PMMA film surface after plasma treatment. We also investigated the refractive index after plasma treatment. In this case, the refractive index was lower than the PMMA film alone. The use of plasma for cladding using PMMA core presents satisfactory results and may be an alternative for polymeric optical devices application.

\section{Acknowledgments}

The authors wish to thank Dr. Marcelo Nelson Páez Carreño (LME/PSI/EPUSP), Dr. Marco-Aurélio de Paoli (IQ/UNICAMP), Dr. Mauricio Kleinke (IFGW/UNICAMP) and Dr. José Alexandre Diniz (DFIS/FEEC/UNICAMP). The research was supported by CAPES and CNPQ (Brazil).

\section{References}

1. Borges, A. M. G., Benetoli, L. O., Licinio, M. A., Zoldan, V. C., Santos-Silva, M. C., Assreuy, J., Pasa, A. A., Debacher, N. A., $\&$ Soldi, V. (2013). Polymers films with surfaces unmodified and modified by non-thermal plasma as new substrates for cell adhesion. Materials Science and Engineering C, 33(3), 1315-1324. PMid:23827577. http://dx.doi.org/10.1016/j. msec.2012.12.031.

2. Kutz, M. (2002). Handbook of materials selection (1520 p.). New York: John Wiley \& Sons.

3. Giacon, V. M., Padilha, G. S., \& Bartoli, J. R. (2015). Fabrication and characterization of polymeric optical by plasma fluorination process. Optik, 126(1), 74-76. http://dx.doi.org/10.1016/j. ijleo.2014.08.152.

4. Hamdy, M. S., Alfaify, S., Al-Hajry, A., \& Yahia, I. S. (2016). Optical constants, photo-stability and photo-degradation of MB/ PMMA thin films for UV sensors. Optik, 127(12), 4959-4963. http://dx.doi.org/10.1016/j.ijleo.2016.02.027.

5. Emslie, C. (1998). Polymer optical fibres: a review. Journal of Materials Science, 23(7), 2281-2293. http://dx.doi.org/10.1007/ BF01111879.

6. Park, S. J., Cho, K. S., \& Choi, C. G. (2003). Effect of fluorine plasma treatment on PMMA and their application to passive optical waveguides. Journal of Colloid and Interface Science, 258(2), 424-426. PMid:12618114. http://dx.doi.org/10.1016/ S0021-9797(02)00094-2.

7. Ceramic Industry. Advances in sol-gel technology. Retrieved in 9 June 2017, from http://www.ceramicindustry.com/ articles/83256-advances-in-sol-gel-technology/

8. Meyerhofer, D. (1978). Characteristics of resist films produced by spinning. Journal of Applied Physics, 49(7), 3993-3997. http://dx.doi.org/10.1063/1.325357.

9. Petri, D. F. S. (2002). Characterization of spin-coated polymer films. Journal of the Brazilian Chemical Society, 13(5), 695699. http://dx.doi.org/10.1590/S0103-50532002000500027.

10. Schubert, D. W. (1997). Spin coating as a method for polymer molecular weight determination. Polymer Bulletin, 38(2), 177-184. http://dx.doi.org/10.1007/s002890050035.

11. Dário,A. F., Macia, H. B., \& Petri, D. F. S. (2012). Nanostructures on spin-coated polymer films controlled by solvent. Thin Solid Films, 524(1), 185-190. http://dx.doi.org/10.1016/j. tsf.2012.10.011.

12. Liu, Z., Zhao, J.-H., Liu, P., \& He, J.-H. (2016). Tunable surface morphology of electrospun PMMA fiber using binary solvent. Applied Surface Science, 364, 516-521. http://dx.doi. org/10.1016/j.apsusc.2015.12.176.

13. Tippo, T., Thanachayanont, C., Muthitamongkol, P., Junin, C., Hietschold, M., \& Thanachayanont, A. (2013). The effects of solvents on the properties of ultra-thin poly (methyl methacrylate) films prepared by spin coating. Thin Solid Films, 546, 180-184. http://dx.doi.org/10.1016/j.tsf.2013.05.022.

14. Mohajerani, E., Farajollahi, F., Mahzoon, R., \& Baghery, S. (2007). Morphological and thickness analysis for PMMA spin coated films. Journal of Optoelectronics and Advanced Materials, 9(12), 3901-3906. Retrieved in 9 June 2017, from https://joam.inoe.ro/index.php?option=magazine\&op=view \&idu $=1125 \&$ catid $=21$

15. Hass, D. E., Quijada, J. N., Picone, S. J., \& Birnie, P. (2003). Effect of solvent evaporation rate on skin formation during spin coating of complex solutions. In Proceedings of SPIE - The International Society for Optical Engineering (pp. 280-284). Bellingham: SPIE.

16. van Krevelen, D. W. (1990). Properties of polymers. Amsterdam: Elsevier.

17. Bartom, A. F. M. (1988). Handbook of solubility parameters and other cohesion parameters. Florida: CRC Press.

18. Chanda, M., \& Roy, S. K. (1987). Plastics technology handbook. New York: Marcel Dekker.

19. Yamamura, M., Nishio, T., Kajiwara, T., \& Adachi, K. (2002). Evaporation-induced pattern formation in polymer films via secondary phase separation. Chemical Engineering Science, 57(15), 2901-2905. http://dx.doi.org/10.1016/S00092509(02)00177-X.

20. Padilha, G. S., Giacon, V. M., \& Bartoli, J. R. (2013). Effect of plasma fluorination variables on the deposition and growth of partially fluorinated polymer over PMMA films. Polimeros: Ciência e Tecnologia, 23(5), 585-589. http://dx.doi.org/10.4322/ polimeros.2013.093.

21. Cicala, G., Milella, A., Palumbo, F., Favia, P., \& d'Agostino, R. (2003). Morphological and structural study of plasma deposited fluorocarbon films at different thicknesses. Diamond and Related Materials, 12(10-11), 2020-2025. http://dx.doi. org/10.1016/S0925-9635(03)00293-0.

22. Kleinke, M. U., Teschke, O., \& Tenam, M. A. (1991). Pattern formation on aluminum electrodes. Journal of the Electrochemical Society, 138(9), 2763-2770. http://dx.doi. org/10.1149/1.2086051.

23. Vargo, T. G., \& Gardella, J. A. (1989). Multitechnique surface spectroscopic studies of plasma modified polymers III. H2O and $\mathrm{O} 2 / \mathrm{H} 2 \mathrm{O}$ plasma modified poly (methyl metacrylate). Journal of Polymer Science, 27(4), 1267-1286. http://dx.doi. org/10.1002/pola.1989.080270413.

24. Guruvenket, S., Rao, G. M., Komath, M., \& Raichur, A. M. (2004). Plasma surface modification of polystyrene and polyethylene. Applied Surface Science, 236(1-4), 278-284. http://dx.doi.org/10.1016/j.apsusc.2004.04.033.

25. Brewis, D. M. (1982). Surface analysis and pretreatment of plastics and metals. London: Applied Science. http://dx.doi. org/10.1002/sia.740040612.

26. Bartoli, J. R., Costa, R. A., Verdonck, P., Mansano, R. D., \& Carreno, M. N. (1998). Filmes ópticos poliméricos fluorados com índice de refração gradual. Polímeros: Ciência e Tecnologia, 9(4), 148-155. http://dx.doi.org/10.1590/S010414281999000400025.

27. Johnston, E. E., \& Ratner, B. D. (1996). Surface characterization of plasma deposited organic thin films. Journal of Electron Spectroscopy and Related Phenomena, 81(3), 303-317. http:// dx.doi.org/10.1016/0368-2048(95)02666-5. 